\title{
Rare Actinobacteria: A Possible Solution for Antimicrobial Drug Resistance in Egypt
}

\author{
Dina Hatem Amin* \\ Department of Microbiology, Ain shams University, Egypt
}

Submission: December 04, 2017; Published: March 15, 2018

*Corresponding author: Dina Hatem Amin, Department of Microbiology, Faculty of Science, Ain shams University, Cairo, Egypt, Email: dina.hatem@sci.asu.edu.eg

\section{Mini Review}

"For every action, there is an equal and opposite reaction" Newton's Third Law of Motion. We can apply this rule on the overuse of antibiotics and the emergence of antimicrobial drug resistance. In the meantime, the uncontrolled practices of antibiotics mainly triggered this problem in both developed and developing countries. The intensity of antimicrobial resistance in developing countries is generally higher because of the excess antibiotics usage.

Antibiotics resistant pathogens are recognized as a gigantic worldwide public health threat, and they have vital effects concerning morbidity, mortality and elevation of healthcare costs Yong et al. [1]. In Egypt, limited data on antimicrobial resistance of food borne and blood borne pathogens were reported El Kholy et al. [2]. However, several individual attempts were performed to tackle antimicrobial resistance statistics. In 2009, Antibiotic resistance and prevalence of Streptococcus pneumoniae, Neisseria meningitidis and Haemophilus influenzae were reported Shaban and Siam [3]. Two years after, Staphylococcus aureus and coagulase-negative Staphylococcus (CNS) isolates obtained from Egyptian hospitals showed oxacillin resistance Hassan et al. [4]. In 2013, the incidence of carbapenem antibiotic resistance of Gramnegative bacteria in Egypt was detected Falagas et al. [5]. In 2015, World Health Assembly in Egypt approved an international action plan to monitor the antimicrobial resistance with some highlights such as raising awareness of community towards antimicrobial resistance through education and training; enhancing data collection to tackle antimicrobial drug resistance surveillance; reducing the risk of infection by suitable sanitation, hygiene and infection avoidance procedures and improving the investment in new medicines, diagnostic tools, vaccines and other involvements. WHO-Egypt action plan ensures the need for a real "one health" approach connecting different global multidisciplinary organizations. I believe that this is a positive action plan and I hope it will fulfill all its approaches to limit this problem. I will discuss the last approach of searching for new medicines from rare actinobacteria. Currently, it is fundamental to discover new antibiotics from distinct strains against multidrug resistant pathogens. Since unusual natural products with new structures will have valuable biological activities Koehn and Carter, Baltz, Amin et al. [6-8].

Rare Actinobacteria has a great potential to produce novel antibiotics [8-12]. My previous work focused on exploring an unordinary group of Actinobacteria, which is known as Rare Actinobacteria [13]. I successfully isolated and identified rare actinomycetes isolates from Egyptian soils and antimicrobial potential of this unique group against some food and blood borne pathogens was observed [14-17]. Rare actinomycetesare difficult to isolate and cultivate by traditional methods. Their isolation needs a pretreatment of tested samples. Various methods are used prior isolation such as (Dry heat treatment $120^{\circ} \mathrm{C}$ for $1 \mathrm{hr}$, Sucrose gradient centrifugation, phenol and SDS treatments) $[13,14]$. This treatments decrease the intensity of fast growers like bacteria, fungi and common Streptomycetes. Hence, promote competence and growth of rare Actinobacteria [18]. Proper selective media having macromolecules similar to casein, chitin, humic acid and enriched with antibiotics are essential for indorsing the growth of rare actinomycetes and overwhelming bacterial and fungal contaminants [19]. Although rare Actinobacteria are isolated in low quantities, molecular tools indicated that they are comparatively abundant in different habitats and they can be recovered in large numbers if suitable isolation methods are accessible [20]. Some genera belonged to this group such as Actinomadura, Actinoplanes, Amycolatopsis, Actinokineospora, Acrocarpospora, Actinosynnema, Catenuloplanes, Cryptosporangium, Dactylosporangium, Kibdelosporangium, Kineosporia, Kutzneria, Microbiospora, Microtetraspora, Nocardia, Nonomuraea, Planomonospora, Planobispora, Pseudonocardia, Saccharomonospora, Saccharopolyspora, Saccharothrix, Streptosporangium, Spirilliplanes, Thermomonospora, Thermobifida, Virgosporangium., Micromonospora and some uncommon species of Streptomyces $[13,18]$. I believe that 
exploring rare actinomycetes, which is difficult to isolate will outcome strains with different genetic diversity and consequently miscellaneous active compounds production.

Another approach should be put into consideration is to create novel structures through gene manipulation of rare actinomycetes genes and cloning them in heterologous hosts which can encode abnormal biosynthetic pathways and hence new activities against resistant pathogens [21]. Proper methodologies' regarding the functional analysis of biosynthetic genes is critical for such approaches. Antibiotic biosynthetic gene clustering using PCR screening assays and Illumina whole genome sequencing give a clear picture for the most possible secondary metabolites pattern produced by rare actinomycetes strains [12,16,17]. In addition to that, Bioinformatics tools for analyzing huge genomic and proteomic data will helps in the field of drug discovery and detecting novel antibiotics $[22,23]$. This is the aim of our research better health for better life.

\section{References}

1. Yong D, Toleman MA, Giske CG, Cho HS, Sundman K, et al. (2009) Characterization of a new metallo- $\beta$-lactamase gene, blaNDM-1, and a novel erythromycin esterase gene carried on a unique genetic structure in Klebsiella pneumoniae sequence type 14 from India. Antimicrobia agents and chemotherapy 53(12): 5046-5054.

2. El Kholy A, Baseem H, Hall GS, Procop GW, Longworth DL (2003) Antimicrobial resistance in Cairo, Egypt 1999-2000: a survey of five hospitals. J Antimicrob Chemother 51(3): 625-630.

3. Shaban L, Siam R (2009) Prevalence and antimicrobial resistance pattern of bacterial meningitis in Egypt. Annals of clinical microbiology and antimicrobials 8(1): 26 .

4. Hassan AM, Ibrahim O, El Guinaidy M (2010) Surveillance of antibiotic use and resistance in orthopaedic department in an Egyptian university hospital. International Journal of Infection Control 7(1): 1-10.

5. Falagas ME, Lourida P, Poulikakos P, Rafailidis PI, Tansarli GS (2013) Antibiotic treatment of infections due to carbapenem-resistant Enterobacteriaceae: systematic evaluation of the available evidence. Antimicrobial agents and chemotherapy 58(2): 654-663.

6. Koehn FE, Carter GT (2005) The evolving role of natural products in drug discovery. Nature Reviews Drug discovery 4(3): 206-220.

7. Baltz RH (2006) Molecular engineering approaches to peptide, polyketide and other antibiotics. Nature biotechnology 24(12): 15331540.

8. Amin DH, Tolba S, Abolmaaty A, Abdallah NA, Wellington EM (2017a) Phylogenetic and antimicrobial characteristics of a novel streptomyces sp Ru87 isolated from Egyptian soil. Int J Curr Microbiol App Sci 6(8): 2524-2541.
9. Hacene H, Daoudi Hamdad F, Bhatnagar T, Baratti JC, Lefebvre G (1999) H107, a new aminoglycoside anti-Pseudomonas antibiotic produced by a new strain of Spirillospora. Microbios 102(402): 69-77.

10. Laidi RF, Kansoh AL, Elshafei AM, Cheikh B (2006) Taxonomy, identification and biological activities of a novel isolate of Streptomyces tendae. Arab J Biotechnol 9(3): 427-436.)

11. Balagurunathan R, Radhakrishnan M (2010) Biotechnological, genetic engineering and nanotechnological potential of actinomycetes. Industrial exploitation of microorganisms, pp: 302-436.

12. Amin DH, Borsetto C, Tolba S, Abolmaaty A, Abdallah NA, et al. (2017b) Phylogenic analysis of NRPS and PKS genes associated with antagonistic micromonospora Rc5 and streptomyces Ru87 isolates. Journal of Advances in Biology and Biotechnology 16 (1): 1-22.

13. Hayakawa M (2008) Studies on the isolation and distribution of rare actinomycetes in soil. Actinomycetologica 22(1): 12-19.

14. Abd Allah N, Tolba S, Hatem D (2012) Selective isolation of rare actinomycetes from different types of Egyptian soil. Egypt J Exp Biol 8(2): 175-182.

15. Tolba ST, Nagwa AAA, Hatem D (2013) Molecular characterization of rare actinomycetes using $16 \mathrm{~S}$ rRNA-RFLP. African Journal of Biological Sciences 9: 185-197".

16. Amin DH, Borsetto C, Abolmaaty A, Tolba S, Abdallah NA, et al. (2017c) Draft genome sequence of antagonistic streptomyces sp. Ru87 isolated from Egyptian soil. Journal of Medical science and Clinical research 5(11): 30219-30221.

17. Amin DH, Borsetto C, Selama O, Abdallah NA, Tolba S, et al. (2017d) Draft Genome Sequence of Micromonospora sp. Rc5 Isolated from desert Egyptian Soil. Journal of Medical science and Clinical research 5(11): 30222-30224.

18. Lazzarini A, Cavaletti L, Toppo G, Marinelli F (2000) Rare genera of actinomycetes as potential producers of new antibiotics. Antonie van Leeuwenhoek 78(3): 399-405.

19. Khanna M, Solanki R, Lal R (2011) Selective isolation of rare actinomycetes producing novel antimicrobial compounds. Int J Adv Biotechnol Res 2(3): 357-375.

20. Sosio M, Donadio S (2004) Exploiting and expanding actinomycete diversity for antibiotic discovery. Microbiology Australia 25(2): 32-33.

21. Walsh TR, Howe RA (2002) The prevalence and mechanisms of vancomycin resistance in Staphylococcus aureus. Annual Reviews in Microbiology 56(1): 657-675.)

22.|Bérdy J (2012) Thoughts and facts about antibiotics: where we are now and where we are heading. The Journal of antibiotics 65(8): 385-395.

23. Amos Gregory, Borsetto Chiara, Laskaris Paris, Krsek Martin, Berry Andrew et al. (2015) Designing and implementing an assay for the detection of rare and divergent NRPS and PKS clones in European, Antarctic and Cuban soils. PLoS ONE 10 (9): e0138327. 
(C) (1) This work is licensed under Creative

DOI: 10.19080/JOJNHC.2018.06.555695

\section{Your next submission with Juniper Publishers will reach you the below assets}

- Quality Editorial service

- Swift Peer Review

- Reprints availability

- E-prints Service

- Manuscript Podcast for convenient understanding

- Global attainment for your research

- Manuscript accessibility in different formats

( Pdf, E-pub, Full Text, Audio)

- Unceasing customer service

Track the below URL for one-step submission https://juniperpublishers.com/online-submission.php 